\title{
KE KOMENSKÉHO SPISU PANSOPHIAE PRODROMUS
}

\section{René Descartes}

Nejváženější a nejvzácnější příteli,

loni jsem četl krátkou knihu o Komenského Snahách ${ }^{2}$ a tomu, kdo mi ji poslal, jsem odpověděl, ${ }^{3}$ že nakolik se mohu dohadovat z obsahu onoho spisu, připadá mi autor nadaný, vzdělaný i zbožný, ale že nepodal jediný doklad, který by dával naději na splnění toho, co slibuje. Ba dokonce, protože, jak se zdá, hodlá lidské vědy mísit s Písmem Svatým a vytvořit jakousi pansofii, kterou by chápaly již děti, projevil jsem obavu, že tím ničeho nedosáhne.

Nyní jsem přečetl rovněž Prodromus Pansophiae 4 spolu s několika dalšími krátkými spisy od téhož Komenského. Pîšeš, že se lidé ptají, co o nich soudím. Protože však neř́íkáš, kdo se ptá, a protože na tebe se mohu přímo obrátit, at' už dotaz vzešel od autora samého či od jeho př́átel, rád bych, abys jim odpověděl, že o té poslední knize nemohu soudit jinak než zcela stejně jako o té první. Věru nemám, co bych řekl potěšujícího a nejsem tak neotesaný, abych hodlal říkat něco ještě méně př́ijemného těm, kteří mě považují za někoho, jehož názor chtějí znát.

Avšak v případě, že dotaz vzešel z jiné strany, od lidí, kteří nejsou zastánci toho či onoho učitele, ale hledají pouze pravdu, aby snad takové nezmýlilo mé mlčení, pak se domnívám, že je vhodné dodat, že tyto spisy nejenže nedávají žádnou naději na to, že by bylo možné dosáhnout

1 Přeloženo podle vydání: J. van de Ven - E.-J. Bos, Se Nihil Daturum Descartes's Unpublished Judgement of Comenius's Pansophiae Prodromus (1639), in: British Journal for History of Philosophy, 12, 2004, str. 369-386. Ke kontextu vzniku dopisu viz S. Sousedík, Descartův soud o Komenského spisu Pansophiae prodromus, str. 111-113 v tomto čísle časopisu. Za redakci překladu děkujeme Pavlu Dudzikovi. - Pozn. red.

2 Jedná se o Komenského spisek Conatuum Comeniorum praeludia ex bibliotheca vydaný Samuelem Hartlibem r. 1637 v Oxfordu. - Pozn. přek1.

3 Komenského odpověd’ je dochována a byla vydána in: Euvres de Descartes, vyd. Ch. Adam - P. Tannery, I-XII, Paris 1897-1913, II, str. 346-348. - Pozn. přek1.

4 „Předchůdce vševědy.“ - Pozn. překl. 
slibovaných [výsledků], ale spíše bezpečně a zřejmě ukazují, že jejich autor není ničeho takového schopen docílit. Vždyt' i kdybych chtěl věřit, že jsou Janua a Vestibulum - knihy, o kterých zeširoka rozkládá, ale které jsem neviděl - velice vhodné $\mathrm{k}$ výuce jazyků, přece však z toho nemohu vyvodit, že by byl tak učený, aby veškeré lidské vědění mohl vyložit v jedné knize, podobně jako bych nesoudil o někom, kdo hraje skvěle na flétnu, že je takový vojevůdce, že si snad může s hrstkou vojáků podmanit celý svět. A třebaže, jak Komenský kdesi připomíná, první linky načrtnuté malîřem na plátno nemohou ukázat celou krásu plánovaného obrazu, přesto však, jsou-li tak neuspořádané a neumělé, že místo Venušiny podoby zobrazují prasečí rypák či lví tlamu, každý hned pozná, že byly nakresleny člověkem zcela neznalým malîrsského umění.

A pominu-li jiná pochybení, lze si snad představit něco méně vhodného než použít k rozdělení Pansofie části chrámu popisované Ezechielem $?^{5}$ A co je nejapnější než sestavit první část Pansofie z prolegomen, v nichž se dokazuje její možnost a snadnost? Jestliže ji totiž v ostatních částech předkládá, nikdo přece nemůže pochybovat, že možná je, takže není třeba, aby to $\mathrm{v}$ oné první části dokazoval. A mimoto nikdo se přece nestane učenější pouze tím, že je přesvědčen, že se učenějším může stát, a tudíž ona prolegomena žádnou část Pansofie netvoří.

A opět, prohlašuje-li, že ve druhé části předloží systém společných pojmů, což nám i zde neukazuje, že nám není s to nabídnout nic [podstatného]? Vždyt' společné pojmy nemohou být jinak, než že jsou známy všem! A dále: není vhodné ani užitečné uvádět je odděleně od jednotlivých vědních odvětví, která jsou z nich vyvozena. Pokud tato odvětví mají být vykládána v ostatních částech Pansofie, všechny společné pojmy se v nich musí zopakovat, takže tato druhá část bude nadbytečná.

Podobně bych mohl ukázat, že žádná ze zbylých částí není správně zařazena do celku, jehož částí je nazývána, a doložit, že autor sám nezná, co chce druhé vyučovat, ale nemyslím, že by mělo cenu déle ztrácet čas vyvrácením [tvrzení], jež jsou tak málo pravděpodobná. A tak zde pouze řeknu, že by se nemělo věřit chemikovi, ${ }^{6}$ který se chvástá, že umí vyrobit zlato, jestliže sám není př́liš bohatý, ani učenci, který slibuje nové

5 Starozákonní prorok Ezechiel poskytuje v 41. kapitole své knihy eschatologickou vizi obnoveného (za jeho dob Babyloňany ve skutečnosti zničeného) jeruzalémského chrámu. Prorokův popis je podrobný. Ve svém spisu Conatuum pansophicorum dilucidatio strukturuje Komenský svůj výklad podle této Ezechielovy vize. - Pozn. př̀k1.

6 Míněn je dobový chemik, tedy alchymista. - Pozn. překl. 
vědy, jestliže neprokáže, že sám objevil mnoho věcí, které byly druhým neznámé.

A i když se může snadno stát, že se najde někdo, kdo by dokázal položit nové základy věd, jež budou mnohem pevnější a stálejší než ty, které jsou dnes k mání, a kdo by ukázal cestu, která by každému, kdo po ní kráčí, dala jistotu, že dojde ke vší vzdělanosti, které je ze své přirozenosti schopen, přece to však nelze uskutečnit, nebudou-li téměř všechny vědy vyučované ve školách reformovány - a to nepochybně ponese celá řada lidí velmi těžce, nebot' z těchto věd žijí a došli díky nim uznání. Nemyslím, že by ten, kdo je dost nadaný, aby se zde [tj. ve vědách] uplatnil, byl tak málo uvážlivý, že by to podnikl, nebo to vůbec byl s to podniknout, leda by měl královský původ nebo byl chráněncem králů či jiných, kteří mají nejvyšší moc nad ostatními lidmi, takže by se nemusel bát žádné nenávisti.

Bud’ zdráv,

S ochotou být Ti ve všem nápomocen, Tvůj Des Cartes ${ }^{7}$

Přeložila Kateřina Šolcová

7 Překlad je výstupem výzkumného projektu GA ČR, 20-03823S, „Jan Marek Marci z Kronlandu (1595-1667) v souvislostech českého filozofického baroka“, který je řešen na FLÚ AV ČR. - Pozn. překl. 